\title{
Pendekatan Regresi Semiparametrik Spline untuk Memodelkan Rata-Rata Umur Kawin Pertama (UKP) di Provinsi Jawa Timur
}

\author{
Dhira Audhia Pratiwi, I Nyoman Budiantara, dan Wahyu Wibowo \\ Jurusan Statistika, Fakultas Matematika dan Ilmu Pengetahuan Alam, Institut Teknologi Sepuluh Nopember (ITS) \\ Jl. Arief Rahman Hakim, Surabaya 60111 Indonesia \\ e-mail:dhiraaudhia@gmail.com, i_nyoman_b@statistika.its.ac.id,wahyu_w@statistika.its.ac.id
}

\begin{abstract}
Abstrak - Penyebab utama pertambahan penduduk yang besar setiap tahunnya adalah kelahiran. Kelahiran erat kaitannya dengan umur kawin pertama. Umur kawin pertama (UKP) adalah umur pada saat wanita menikah pertama kali. Jawa Timur memiliki rata-rata UKP wanita sebesar 22 tahun, dan merupakan terendah kedua di Pulau Jawa setelah Banten. Sebanyak lebih dari 50 persen wanita di Jawa Timur kawin di usia kurang dari 20 tahun pada tahun 2012. Terdapat 5 faktor yang diduga mempengaruhi UKP, yaitu persentase penduduk yang tinggal di pedesaan, rata-rata lama sekolah wanita, persentase penduduk usia 15 tahun ke atas yang bekerja, persentase penduduk miskin, dan gini ratio. Pemodelan UKP menggunakan regesi semiparametrik spline linier karena hubungan antara rata-rata UKP wanita Provinsi Jawa Timur dengan sebagian faktor yang diduga mempengaruhinya tidak membentuk pola tertentu dan sebagian lagi membentuk pola tertentu. Berdasarkan hasil analisis, terdapat 4 faktor yang berpengaruh signifikan terhadap rata-rata UKP, yaitu rata-rata lama sekolah wanita, persentase penduduk wanita yng tinggal di desa, persentase penduduk wanita usia 15 tahun keatas yang bekerja, dan gini ratio. Model regresi semiparametrik spline menghasilkan koefisien determinasi sebesar $\mathbf{9 0 , 7 7 \%}$.
\end{abstract}

Kata Kunci-rata-rata umur kawin pertama, regresi semiparametrik, spline.

\section{PENDAHULUAN}

$\mathrm{F}$ ENOMENA pertambahan maupun penurunan penduduk yang besar setiap tahunnya dipengaruhi oleh tiga faktor, yaitu fertilitas (kelahiran), mortalitas (kematian), dan migrasi atau perpindahan penduduk [1]. Berdasarkan bentuk piramida penduduk Indonesia yang lebar pada bagian bawah, dapat dipastikan bahwa faktor utama yang mempengaruhi laju pertumbuhan penduduk adalah tingkat fertilitas (kelahiran). Kelahiran erat kaitannya dengan usia kawin pertama [2]. Semakin cepat seorang wanita kawin, maka masa reproduksinya akan semakin panjang dan kemungkinan banyaknya keturunan juga akan semakin tinggi [3]. Umur kawin pertama (UKP) adalah umur pada saat wanita menikah pertama kali atau pada saat mereka memulai hubungan dengan pasangan yang pertama [4].

Jawa Timur memiliki rata-rata UKP wanita sebesar 22 tahun, dan merupakan terendah kedua di Pulau Jawa setelah Provinsi Banten yang memiliki rata-rata UKP 21,5 tahun.
Berdasarkan data dari BKKBN pula, persentase wanita di Jawa Timur pada tahun 2012 yang berstatus kawin menurut usia pada perkawinan pertama, sebanyak lebih dari 50 persen wanita kawin di usia kurang dari 20 tahun. Hal ini tentunya mempengaruhi rendahnya rata-rata Umur Kawin Pertama wanita di Provinsi Jawa Timur.

Penelitian mengenai rata-rata UKP pernah dilakukan oleh Imawati (2012), Ananto (2014), Lehrer dan Chen (2013, dan Syilfi (2015). Secara keseluruhan, faktor yang mempengaruhi rata-rata UKP berkaitan dengan faktor ekonomi, sosial, dan budaya. Berdasarkan referensi pada penelitian-penelitian sebelumnya, terdapat beberapa variabel yang diduga mempengaruhi rata-rata UKP wanita di Provinsi Jawa Timur, variabel-variabel tersebut terkait aspek ekonomi, sosial, dan budaya.

Salah satu metode analisis yang dapat digunakan untuk mengetahui faktor-faktor apa saja yang mempengaruhi ratarata UKP wanita adalah menggunakan analisis regresi. Terdapat tiga pendekatan yang dapat dilakukan untuk mengestimasi kurva regresi, yaitu regresi parametrik, regresi nonparametrik, dan regresi semiparametrik. Persentase penduduk wanita usia 15 tahun ke atas yang bekerja secara teori dapat mempengaruhi rata-rata umur kawin pertama di suatu provinsi, dimana semakin banyak wanita yang bekerja, maka rata-rata umur kawin pertama di suatu provinsi juga akan semakin tinggi, atau semakin tua wanita menikah. Namun berdasarkan data yang diperoleh, Kabupaten Pacitan yang memiliki persentase penduduk wanita usia 15 tahun ke atas yang bekerja tinggi, rata-rata UKP nya tergolong dalam early marriage, begitu juga dengan Kabupaten Sumenep. Fakta ini tentunya tidak sesuai dengan teori yang ada dan menunjukkan pola yang nonparametrik. Sementara pada data persentase penduduk miskin per kabupaten di Jawa Timur membentuk pola yang parametrik. Dimana semakin tinggi persentase penduduk miskinnya, maka rata-rata UKP nya semakin rendah. Hubungan antara rata-rata UKP wanita Provinsi Jawa Timur dengan sebagian faktor yang diduga mempengaruhinya tidak membentuk pola tertentu dan sebagian lagi membentuk pola tertentu sehingga digunakan pemodelan regresi semiparametrik dengan pendekatan spline. 


\section{TINJAUAN PUSTAKA}

\section{A. Regresi Semiprametrik Spline}

Regresi semiparametrik merupakan salah satu metode statistika yang digunakan untuk mengetahui pola hubungan antara variabel respon dan prediktor dimana sebagian diketahui bentuk polanya, dan sebagian tidak diketahui bentuknya. Misal terdapat data berpasangan $\left(x_{i}, y_{i}, t_{i}\right)$ dan hubungan antara $x_{i}, y_{i}$, dan $t_{i}$ diasumsikan mengikuti model regresi sebagai berikut.

$$
y_{i}=\mathbf{x}_{i} \boldsymbol{\beta}+f\left(t_{i}\right)+\varepsilon_{i}, i=1,2, \ldots, n
$$

Regresi semiparametrik bisa juga disebut sebagai gabungan dari regresi parametrik dan regresi nonparametrik. Regresi parametrik adalah metode yang digunakan untuk mengetahui pola hubungan antara variabel respon dan prediktor dimana bentuk kurva regresi diketahui. Model regresi parametrik linear berganda dalam bentuk matriks adalah sebagai berikut.

$$
\mathbf{y}=\mathbf{X} \boldsymbol{\beta}+\varepsilon
$$

dengan $y$ adalah vektor kolom berukuran $n \quad x \quad 1$ yang elemennya berupa data respon, $\mathrm{X}$ merupakan matrik berukuran $n x(m+1)$ dengan elemen berupa data $m$ prediktor, dan $\varepsilon$ adalah vektor kolom berukuran $n \times 1$ dengan elemen berupa error random. Estimasi parameter pada regresi parametrik diperoleh dengan menggunakan metode estimasi Ordinary Least Square (OLS) sebagai berikut.

$$
\$=\left(\mathbf{X}^{\prime} \mathbf{X}\right)^{-1} \mathbf{X}^{\prime} \mathbf{y}
$$

Sementara regresi nonparametrik merupakan metode statistika yang digunakan apabila pola data yang tidak diketahui bentuk kurva regresinya atau tidak terdapat informasi masa lalu yang lengkap tentang bentuk pola data [5]. Regresi nonparametrik spline merupakan regresi yang sangat fleksibel dalam memodelkan pola data. Model regresi nonparametrik spline secara umum adalah sebagai berikut.

$$
y_{i}=f\left(t_{i}\right)+\varepsilon_{i}, i=1,2,3, \ldots, n
$$

dimana $y_{i}$ adalah variabel respon, $t_{i}$ adalah variabel prediktor, $f\left(x_{i}\right)$ adalah fungsi regresi yang polanya tidak diketahui, serta $\varepsilon_{i} \sim \operatorname{IIDN}\left(0, \sigma^{2} I\right)$. Pada model regresi nonparametrik spline, kurva regresi dihampiri dengan fungsi spline berorde $p$ dengan titik knot $k_{1}, k_{2}, \ldots, k_{r}$ dalam bentuk.

$$
f\left(\mathrm{t}_{i}\right)=\sum_{j=0}^{p} \gamma_{j} t_{i}^{j}+\sum_{i=1}^{r} \gamma_{p+l}\left(\mathrm{t}_{i}-k_{l}\right)_{+}^{p}
$$

dengan $\gamma$ adalah parameter model, $p$ adalah orde spline dan $k$ adalah banyak knot spline. Berdasarkan persamaan (4) dan (5) dapat diperoleh persamaan regresi seperti berikut.

$$
y_{i}=\sum_{j=0}^{p} \gamma_{j} t_{i}^{j}+\sum_{l=1}^{r} \gamma_{p+l}\left(\mathrm{t}_{i}-k_{l}\right)_{+}^{p}+\varepsilon_{i}, i=1,2, \ldots, n
$$

Fungsi truncated adalah sebagai berikut.

$$
\left(t_{i}-k_{l}\right)_{+}^{p}= \begin{cases}\left(t_{i}-k_{l}\right)^{p} & , t_{i} \geq k_{l} \\ 0 & , t_{i}<k_{l}\end{cases}
$$

Estimator spline dalam regresi nonparametrik dapat menangani fungsi yang bersifat smooth [6]. Estimasi regresi nonparametrik spline truncated dapat diperoleh dengan metode Ordinary Least Square (OLS). Hasil estimasi adalah sebagai berikut.

$$
\$(\mathbf{k})=\left(\mathbf{T}(\mathbf{k})^{\prime} \mathbf{T}(\mathbf{k})\right)^{-1} \mathbf{T}(\mathbf{k})^{\prime} \mathbf{y}
$$

Dimana $\mathbf{T}(\mathbf{k})$ merupakan variabel prediktor komponen nonparametrik yang sudah mengandung titik knot masingmasing. Model regresi spline terbaik diperoleh dari titik knot yang optimal. Titik knot yang optimal diperoleh dari nilai GCV minimum. GCV merupakan modifikasi dari metode CV (Cross Validation) dan merupakan metode yang paling banyak dipakai dan disukai karena memiliki sifat optimal asimtotik. [7]. Titik knot optimal diperoleh dari nilai GCV minimum. Metode GCV dapat dituliskan sebagai berikut [8].

$$
G C V(k)=\frac{\operatorname{MSE}(k)}{\left[n^{-1} \operatorname{trace}(\mathbf{I}-\mathbf{A}(\mathbf{k})]^{2}\right.}
$$

dengan I adalah matriks identitas dan $n$ adalah jumlah pengamatan.

$$
\operatorname{MSE}(k)=n^{-1} \sum_{i=1}^{n}\left(y_{i}-\$_{i}\right)^{2},
$$

\section{B. Ukuran Kebaikan Model}

Setelah diperoleh model yang sesuai, perlu diukur seberapa besar kebaikan model tersebut. Nilai kebaikan model diberikan oleh nilai $R$-square yang ditunjukkan dengan persamaan sebagai berikut.

$$
R^{2}=\frac{S S R}{S S T}=\frac{\mathbf{b}^{\prime} \mathbf{X}(\mathbf{k})^{\prime} \mathbf{y}-n \mathbf{y}^{-2}}{\left(\mathbf{y}^{\prime} \mathbf{y}\right)^{\prime}-\overline{\mathbf{y}}^{2}}
$$

Dimana $X(k)$ merupakan gabungan variabel prediktor komponen parametrik dan komponen nonparametrik yang telah mengandung titik knot masing-masing.

\section{Pengujian Parameter Model}

1. Pengujian Parameter Model Secara Serentak

Uji serentak dilakukan untuk mengetahui signifikasi parameter model regresi secara bersama-sama. Berikut ini merupakan hipotesis untuk uji serentak.

$H_{0}: \beta_{1}=\beta_{2}=\ldots=\beta_{m}=\gamma_{1}=\gamma_{2}=\ldots=\gamma_{p+r}=0$

$H_{1}$ : paling sedikit ada satu $\gamma_{j} \neq 0$ atau $\beta_{k} \neq 0$

$j=1,2, \ldots, p+r, k=1,2, \ldots, m$

dengan $p+r$ merupakan parameter regresi nonparametrik. Statistik uji yang digunakan adalah sebagai berikut.

$$
F_{\text {hit }}=\frac{M S R}{M S E}
$$

dimana $M S E=\frac{\mathbf{y}^{\prime} \mathbf{y}-\mathbf{b}^{\prime} \mathbf{X}(\mathbf{k})^{\prime} \mathbf{y}}{n-(m+p+r+1)}$ dan

$M S R=\frac{\mathbf{b}^{\prime} \mathbf{X}(\mathbf{k})^{\prime} \mathbf{y}-n \bar{y}^{2}}{m+p+r}$

Kesimpulan Tolak $H_{0}$ jika $F_{\text {hitung }}$ lebih besar daripada $F_{\alpha ;(m+(p+r), n-(m+(p+r)-1)}$ atau $p$-value $<\alpha$ yang menunjukkan bahwa paling sedikit terdapat satu parameter yang signifikan terhadap model. 
2. Pengujian Parameter Model Secara Individu

Pengujian parameter secara individu dilakukan apabila pengujian parameter model secara serentak diperoleh kesimpulan bahwa minimal terdapat satu parameter yang signifikan. Berikut ini merupakan hipotesis dari pengujian parameter secara individu.

$H_{0}: \beta_{k}=0$

$H_{1}: \beta_{k} \neq 0, k=1,2, \ldots, m$

Sedangkan berikut merupakan hipotesis untuk parameter regresi nonparametrik.

$H_{0}: \gamma_{j}=0$

$H_{1}: \gamma_{j} \neq 0 ; j=1,2, \ldots, p+r$

Statistik uji disajikan sebagai berikut.

$$
\begin{gathered}
t_{h i t}=\frac{\hat{\beta}_{k}}{\operatorname{se}\left(\hat{\beta}_{k}\right)} \text { (untuk parameter parametrik) } \\
t_{h i t}=\frac{\hat{\gamma}_{j}}{\operatorname{se}\left(\hat{\gamma}_{j}\right)} \text { (untuk parameter nonparametrik) }
\end{gathered}
$$

\section{Pengujian Asumsi Residual}

\section{Asumsi Identik}

Asumsi identik terpenuhi jika varians respon sama dengan varians error yaitu sama dengan $\sigma^{2}$. Hal tersebut merupakan asumsi homoskedastisitas (varians sama) atau disebut dengan identik [9]. Kasus heteroskedastisitas dapat dideteksi menggunakan uji glejser dan dilakukan dengan cara meregresikan harga mutlak residual dengan variabel prediktor. Berikut ini merupakan hipotesis uji glejser.

$H_{0}: \sigma_{1}^{2}=\sigma_{2}^{2}=\ldots=\sigma_{n}^{2}=\sigma^{2}$

$H_{1}$ : minimal ada satu $\sigma_{i}^{2} \neq \sigma^{2}, i=1,2, \ldots, n$

Statistik uji yang digunakan adalah sebagai berikut.

$$
F_{\text {hit }}=\frac{M S R_{\text {glejser }}}{M S E_{\text {glejer }}}
$$

dimana $M S E_{\text {glejser }}=\frac{|\boldsymbol{\varepsilon}|^{\prime}|\boldsymbol{\varepsilon}|-\mathbf{b}^{\prime} \mathbf{X}(\mathbf{k})^{\prime}|\boldsymbol{\varepsilon}|}{n-(m+p+r)-1}$ dan

$M S R_{\text {glejser }}=\frac{\mathbf{b}^{\prime} \mathbf{X}(\mathbf{k})^{\prime}|\boldsymbol{\varepsilon}|-\left.n||^{2}\right|^{2}}{m+p+r}$

$H_{0}$ ditolak apabila $F_{h i t}>F_{\alpha,(m+(p+r), n-(m+(p+r))-1)}$ atau p-value

kurang dari $\alpha$. Apabila $H_{0}$ ditolak, maka dapat disimpulkan bahwa terjadi heteroskedastisitas yang artinya asumsi residual identik tidak terpenuhi.

\section{Asumsi Independen}

Asumsi klasik kedua yang harus dipenuhi adalah residual bersifat independen. Asumsi residual independen yaitu asumsi bahwa tidak ada korelasi antar residual atau adanya independensi pada residual yang ditunjukkan dengan nilai kovarian antara $\varepsilon_{i}$ dan $\varepsilon_{j}$ sama dengan nol.

Uji independen dilakukan menggunakan interval konfidensi untuk $\rho_{k}$ dengan hipotesis sebagai berikut.
$H_{0}: \operatorname{cov}\left(\varepsilon_{i}, \varepsilon_{j}\right)=0$

$H_{1}$ : paling sedikit ada satu $\operatorname{cov}\left(\varepsilon_{i}, \varepsilon_{j}\right) \neq 0, i \neq j$

Rumus interval konfidensi adalah sebagai berikut.

$$
-t_{n-1, \alpha / 2} \operatorname{se}\left(\hat{\rho}_{k}\right)<\rho_{k}<t_{n-1, \alpha / 2} \operatorname{se}\left(\hat{\rho}_{k}\right)
$$

Apabila tidak terdapat autokorelasi yang keluar dari batas signifikansi, maka dapat disimpulkan bahwa asumsi residual independen terpenuhi.

3. Asumsi Distribusi Normal

Asumsi residual berdistribusi normal dilakukan untuk mengetahui apakah residual hasil regresi telah berdistribusi normal atau tidak. Cara lain dapat dilakukan untuk menguji asumsi residual berdistribusi normal adalah berdasarkan visual menggunakan normal probability plot residual yang cenderung mengikuti garis atau menggunakan uji Kolmogorov Smirnov. Apabila menggunakan uji Kolmogorov-Smirnov, berikut merupakan hipotesis yang digunakan.

$H_{0}: F_{0}(x)=S_{N}(x)$ (Residual berdistribusi Normal)

$H_{1}: F_{0}(x) \neq S_{N}(x)$ (Residual tidak berdistribusi Normal)

Statistik uji yang digunakan adalah

$$
D=\operatorname{maks}\left|F_{0}(x)-S_{N}(x)\right|
$$

Daerah penolakan $H_{0}$ jika $|D|>q_{(1-\alpha)}$ dimana nilai $q_{(1-\alpha)}$ adalah berdasarkan tabel Kolmogorov-Smirnov atau dapat juga berdasarkan $p$-value $<\alpha$.

\section{E. Umur Kawin Pertama}

Umur kawin pertama adalah umur pada saat wanita menikah pertama kali atau pada saat wanita memulai kehidupan dengan pasangan yang pertama dinikahinya [2]. Semakin muda usia kawin pertama yang dilakukan seseorang, maka akan mempengaruhi tingkat fertilitas dan fekunditas (potensi fisik untuk melahirkan anak). Tingginya tingkat kelahiran akan menyebabkan meningkatnya pertumbuhan penduduk suatu [3]. BKKBN menetapkan usia kawin yang ideal untuk wanita adalah diatas 20 tahun dan 25 tahun untuk laki-laki. Umur Kawin Pertama (UKP) wanita dikelompokkan menjadi 4 kelompok, yaitu.

1. UKP wanita kurang dari 18 tahun, dikelompokkan ke dalam Child Marriage.

2. UKP wanita antara 18 tahun hingga kurang dari 20 tahun, disebut dengan Early Marriage.

3. UKP wanita antara 20 hingga kurang dari 22 tahun, disebut dengan Marriage at Maturity.

4. UKP wanita diatas 22 tahun, disebut dengan Late Marriage.

Pengelompokan UKP wanita tersebut merupakan pengelompokan secara individu atau perseorangan.

\section{METODOLOGI PENELITIAN}

\section{A. Sumber Data}

Data yang digunakan dalam penelitian ini adalah data sekunder yang diperoleh dari beberapa sumber yaitu "Hasil Survei Sosial Ekonomi Nasional Tahun 2012", "Data dan Informasi Kemiskinan Kabupaten/Kota Propinsi Jawa Timur Tahun 2012" yang dipublikasikan oleh Badan Pusat Statistik 
Jawa Timur. Unit penelitian adalah 29 kabupaten yang ada di Jawa Timur.

\section{B. Variabel Penelitian}

Penelitian ini menggunakan respon $y$ adalah rata-rata UKP wanita per kabupaten di Propinsi Jawa Timur. Variabel prediktor $x$ adalah faktor-faktor yang diduga mempengaruhi rata-rata UKP wanita Propinsi Jawa Timur. Berikut merupakan variabel-variabel tersebut.

Tabel 1.

Variabel Penelitian

\begin{tabular}{clc}
\hline \hline Variabel & \multicolumn{1}{c}{ Keterangan } & Skala \\
\hline$y$ & Rata-rata UKP wanita & Kontinu \\
$x_{1}$ & $\begin{array}{l}\text { Persentase penduduk wanita yang tinggal di } \\
\text { pedesaan }\end{array}$ & Kontinu \\
$x_{2}$ & $\begin{array}{l}\text { Rata-rata lama sekolah wanita } \\
x_{3}\end{array}$ & $\begin{array}{l}\text { Persentase penduduk wanita berusia 15 tahun } \\
\text { ke atas yang bekerja }\end{array}$ \\
$x_{4}$ & Persentase penduduk miskin & Kontinu \\
$x_{5}$ & Gini Ratio & Kontinu \\
\hline \hline
\end{tabular}

\section{Langkah Penelitian}

Mengacu pada tujuan penelitian, berikut merupakan langkah analisis dalam penelitian ini.

1. Tujuan pertama yaitu mengetahui karakteristik rata-rata Umur Kawin Pertama (UKP) wanita dan faktor-faktor yang diduga mempengaruhinya di Propinsi Jawa Timur dipenuhi dengan melakukan langkah-langkah sebagai berikut.
a. Mendeskripsikan data rata-rata Umur Kawin Pertama dan faktor yang diduga mempengaruhinya di Propinsi Jawa Timur.
b. Membuat scatter plot pada masing-masing variabel bentuk pola data. prediktor dengan variabel respon untuk mengetahui
c. Menentukan variabel yang mempunyai pola tertentu (parametrik) dan variabel yang tidak mempunyai pola tertentu (nonparametrik).

2. Tujuan kedua yaitu memodelkan rata-rata Umur Kawin Pertama (UKP) di Propinsi Jawa Timur menggunakan pendekatan regresi semiparametrik spline dipenuhi dengan melakukan langkah sebagai berikut.
b. Memilih titik knot optimal berdasarkan nilai GCV yang paling minimum.
c. Mendapatkan model regresi semiparametrik spline terbaik dengan titik knot optimal.

d. Menguji kebaikan model dengan menghitung $R^{2}$.
e. Melakukan uji signifikansi parameter secara serentak dan parsial.

f. Melakukan uji asumsi residual IIDN dari model regresi spline

Setelah melakukan analisis, maka membuat kesimpulan dari hasil analisis.

\section{ANALISIS DAN PEMBAHASAN}

\section{A. Karakteristik Data}

Rata-rata Umur Kawin Pertama dapat dikategorikan menjadi 4 kategori, rata-rata UKP wanita kurang dari 18 tahun dikelompokkan ke dalam Child Marriage, rata-rata UKP wanita antara 18 tahun hingga kurang dari 20 tahun disebut dengan Early Marriage, rata-rata UKP wanita antara 20 hingga kurang dari 22 tahun disebut dengan Marriage at Maturity, dan rata-rata UKP wanita diatas 22 tahun disebut dengan Late Marriage.

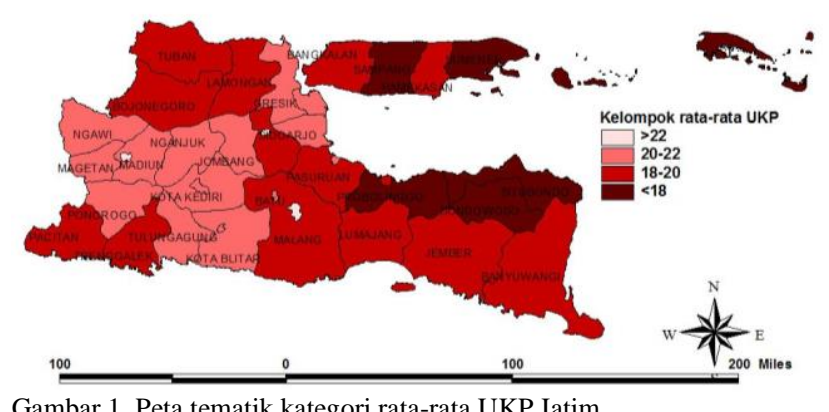

Gambar 1. Peta tematik kategori rata-rata UKP Jatim

Berdasarkan Gambar 1, rata-rata UKP wanita di setiap kabupaten Provinsi Jawa Timur bervariasi, terdapat 4 kategori rata-rata UKP yang tersebar di seluruh provinsi.

Tabel 2.

Jumlah Kabupaten pada Setiap Kategori UKP

\begin{tabular}{cc}
\hline Kategori & Jumlah Kab/Kota \\
\hline Child Marriage & 5 \\
Early Marriage & 13 \\
Marriage at Mature & 11 \\
Late Marriage & - \\
\hline
\end{tabular}

Berdasarkan Tabel 2, keempat kategori rata-rata UKP tersebar di Jawa Timur. 5 kabupaten tergategorikan menjadi child marriage, 13 kabupaten terkategorikan ke dalam early marriage, 11 kabupaten/kota terkategorikan ke dalam marriage at mature, dan tidak terdapat kabupaten terkategorikan ke dalam late marriage.

Terdapat beberapa variabel yang diduga berpengaruh terhadap rata-rata umur kawin pertama di Provinsi Jawa Timur. Sebelum melakukan pemodelan, perlu diketahui karakteristik setiap variabel.

Tabel 3. Karakteristik Variabel Penelitian

\begin{tabular}{|c|c|c|c|c|c|}
\hline & Keterangan & $\operatorname{Max}$ & Min & Mean & Varian \\
\hline$x_{1}$ & $\begin{array}{l}\text { Persentase penduduk } \\
\text { wanita yang tinggal di } \\
\text { pedesaan }\end{array}$ & 87.34 & 8.74 & 63.86 & 292.79 \\
\hline$x_{2}$ & $\begin{array}{l}\text { Rata-rata lama sekolah } \\
\text { wanita }\end{array}$ & 9.49 & 3.66 & 6.492 & 1.376 \\
\hline$x_{3}$ & $\begin{array}{l}\text { Persentase penduduk } \\
\text { wanita berusia } 15 \text { tahun } \\
\text { ke atas yang bekerja }\end{array}$ & 56.44 & $\begin{array}{c}31.2 \\
1\end{array}$ & 42.38 & 43.64 \\
\hline$x_{4}$ & $\begin{array}{l}\text { Persentase penduduk } \\
\text { miskin }\end{array}$ & 27.87 & 6.42 & 14.767 & 23.149 \\
\hline$x_{5}$ & Gini Ratio & 0.43 & 0.24 & 0.3069 & 0.00154 \\
\hline
\end{tabular}

Berdasarkan Tabel 3, persentase penduduk yang tinggal di pedesaan tertinggi di Jawa Timur dari seluruh kabupaten 
adalah $87,34 \%$, yaitu di Kabupaten Sampang, dan terendah adalah 8,74\% dimiliki oleh Kabupaten Sidoarjo. Kabupaten dengan rata-rata lama sekolah wanita terkecil adalah di Kabupaten Sampang, yaitu hanya selama 3,66 tahun dan tertinggi terjadi di Kabupaten Sidoarjo yaitu selama 9,49 tahun. Kabupaten dengan persentase penduduk wanita usia 15 tahun keatas yang bekerja tertinggi adalah di Kabupaten Pacitan yaitu sebesar 56,44\% dan terendah Kabupaten Gresik yaitu sebesar $31,21 \%$. Persentase penduduk miskin tertinggi terjadi di Kabupaten Sampang yang mencapai 27,87 persen dan terendah di Kabupaten Sidoarjo yaitu sebesar 6,42\%. Gini ratio terkecil sebesar 0,24 terjadi di Kabupaten Pamekasan. Hal ini berarti ketimpangan kekayaan di Kabupaten Pamekasan termasuk dalam kategori ketimpangan rendah. Sementara gini ratio tertinggi sebesar 0,43 terjadi di Kabupaten Gresik.

\section{B. Pola Data Antara Rata-rata UKP dengan Variabel yang Diduga Mempengaruhi}

Berikut merupakan scatter plot yang menyatakan bentuk pola data antara rata-rata UKP dan variabel-variabel yang diduga mempengaruhinya.

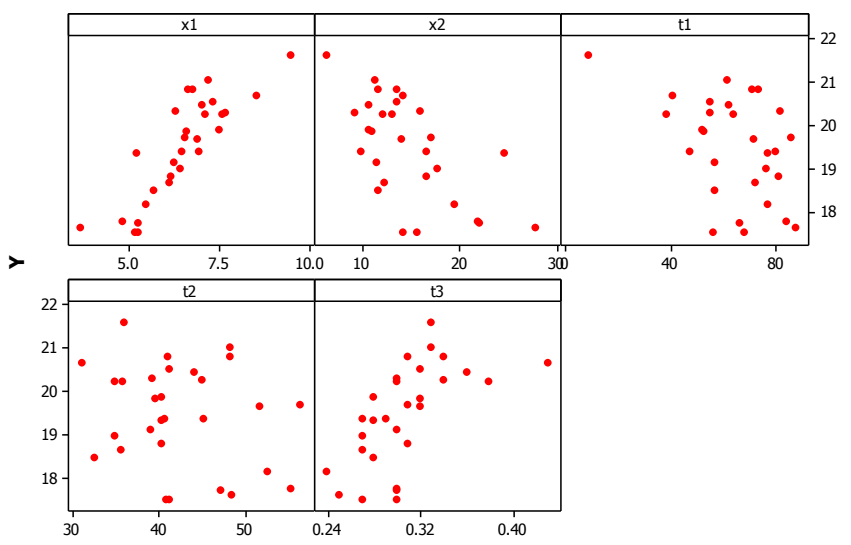

Gambar 2. Scatterplot variabel prediktor terhadap respon

Berdasarkan Gambar 2, dapat diketahui bahwa sebagian dari lima pola data tidak membentuk suatu pola tertentu (persentase penduduk yang tinggal di desa, persentase penduduk wanita yang tinggal di desa, dan gini ratio), dan sebagian lagi membentuk pola tertentu (linier), yaitu persetase penduduk miskin dan rata-rata lama sekolah wanita. Dengan demikian, dalam pemodelan regresi akan digunakan pendekatan regresi semiparametrik.

\section{Pemilihan Titik Knot Optimal}

Nilai GCV minimum pada pemilihan titik knot optimal dengan satu titik knot, dua titik knot, tiga titik knot, dan kombinasi titik knot ditampilkan sebagai berikut.

Tabel 4.

\begin{tabular}{|c|c|}
\hline Model & GCV \\
\hline $1 \mathrm{Knot}$ & 0,445144 \\
\hline $2 \mathrm{Knot}$ & 0,406152 \\
\hline 3 Knot & 0,366851 \\
\hline Kombinasi Knot 3,3,2 & 0,360111 \\
\hline
\end{tabular}

Berdasarkan Tabel 4, nilai GCV yang paling minimum dimiliki oleh model dengan kombinasi titik knot 3,3,2, yaitu sebesar 0,360111.

D. Penaksiran Parameter Model Regresi Semiparametrik Spline

Berdasarkan nilai GCV terkecil, didapatkan model terbaik yaitu model regresi nonparametrik spline dengan kombinasi knot 3,3,2. Berikut ini adalah hasil estimasi parameter model regresi semiparametrik spline terbaik.

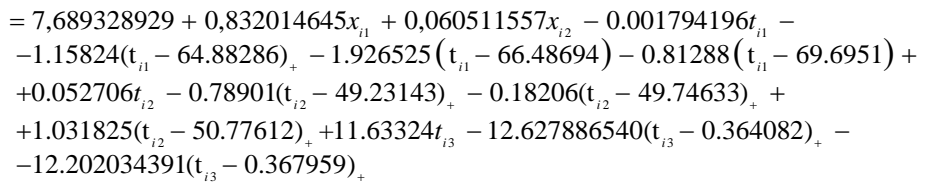

\section{E. Pengujian Signifikansi Parameter Model Regresi Nonparametrik Spline}

1. Uji Serentak

Pengujian secara serentak ini dilakukan untuk menguji estimasi parameter model secara bersamaan (simultan). Nilai $\alpha$ yang digunakan sebesar 0,05 dengan hipotesis sebagai berikut.

\section{$H_{0}: \beta_{1}=\beta_{2}=\gamma_{11}=\gamma_{21}=\ldots=\gamma_{33}=0$ \\ $H_{1}$ : paling sedikit ada satu $\gamma_{j} \neq 0$ atau $\beta_{k} \neq 0$}

Berikut ini adalah hasil analisis ragam model regresi nonparametrik spline.

Tabel 5. Analisis Ragam Uji Serentak

\begin{tabular}{cccccc}
\hline Sumber & df & SS & MS & Fhit & P-value \\
\hline Regresi & 13 & 35.27132 & 2.713179 & 11.34053 & $1.68 \mathrm{E}-05$ \\
Error & 15 & 3.588693 & 0.2392462 & & \\
Total & 28 & 38.86002 & & & \\
\hline
\end{tabular}

Berdasarkan Tabel 5 didapat p-value 1,68E-05. Menggunakan taraf signifikansi $(\alpha)$ sebesar 0,05 , keputusan yang dapat diambil dari uji serentak adalah tolak $H_{0}$ sehingga terdapat minimal satu variabel prediktor yang berpengaruh terhadap rata-rata UKP di Jawa Timur. Untuk mengetahui parameter mana yang signifikan dalam model, dilakukan pengujian secara individu.

2. Uji Individu

Pengujian secara individu dilakukan untuk mengetahui variabel yang berpengaruh signifikan terhadap jumlah penganguran di Indonesia. . Berikut merupakan hipotesis untuk parameter regresi parametrik.

$H_{0}: \beta_{k}=0$

$H_{1}: \beta_{k} \neq 0, k=1,2$

Sedangkan berikut merupakan hipotesis untuk parameter regresi nonparametrik.

$H_{0}: \gamma_{j}=0$

$H_{1}: \gamma_{j} \neq 0 ; j=1,2, \ldots, 11$

Berikut ini adalah hasil pengujian signifikansi parameter model secara individu.

Berdasarkan Tabel 6, terdapat satu variabel yang tidak signifikan berengaruh terhadap rata-rata UKP Jawa Timur, yaitu $x_{2}$ (persentase penduduk miskin). Pemodelan kembali 
dengan menghapus variabel yang tidak signifikan tidak perlu dilakukan karena sebenarnya variabel yang tidak berpengaruh signifikan terhadap rata-rata umur kawin pertama tersebut masih tetap dapat dimasukkan ke dalam model hanya tidak perlu diinterpretasi.

Tabel 6.

Hasil Uji Individu

\begin{tabular}{ccccc}
\hline \hline Variabel & Parameter & Estimasi & P-Values & Kesimpulan \\
\hline$x_{1}$ & $\beta_{1}$ & 0.832015 & 0.000442 & Signifikan \\
$x_{2}$ & $\beta_{2}$ & 0.060512 & 0.215171 & Tidak Signifikan \\
$t_{1}$ & $\gamma_{11}$ & -0.00179 & 0.894285 & Tidak Signifikan \\
& $\gamma_{21}$ & -1.15824 & 0.010115 & Signifikan \\
& $\gamma_{31}$ & -1.926525 & 0.006228 & Signifikan \\
& $\gamma_{41}$ & -0.81288 & 0.007869 & Signifikan \\
& $\gamma_{12}$ & 0.052706 & 0.062187 & Tidak Signifikan \\
& $\gamma_{22}$ & -0.78901 & 0.067009 & Tidak Signifikan \\
& $\gamma_{32}$ & -0.18206 & 0.021699 & Signifikan \\
& $\gamma_{42}$ & 1.031825 & 0.108969 & Tidak Signifikan \\
& $\gamma_{13}$ & 11.63324 & 0.025406 & Signifikan \\
& $\gamma_{23}$ & -12.6279 & 0.086487 & Tidak Signifikan \\
& $\gamma_{33}$ & -12.202 & 0.085652 & Tidak Signifikan \\
\hline \hline
\end{tabular}

\section{F. Pengujian Asumsi Residual}

1. Asumsi Identik

Uji identik pada residual dilakukan menggunakan uji Glejser dengan hipotesis sebagai berikut.

$H_{0}: \sigma_{1}^{2}=\sigma_{2}^{2}=\ldots=\sigma_{n}^{2}=\sigma^{2}$

$H_{1}$ : paling sedikit ada satu $\sigma_{i}^{2} \neq \sigma^{2}$

Berikut merupakan hasil uji Glejser pada residual.

Tabel 10.

Analisis Ragam Uji Glejser

\begin{tabular}{cccccc}
\multicolumn{7}{c}{ Analisis Ragam Uji Glejser } \\
\hline \hline Sumber & df & SS & MS & Fhit & P-value \\
\hline Regresi & 13 & 0.6085 & 0.046811 & 0.727414 & 0.714682 \\
Error & 15 & 0.9652 & 0.064353 & & \\
Total & 28 & 1.5738 & & & \\
\hline \hline
\end{tabular}

Berdasarkan Tabel $10 p$-value adalah sebesar 1,50756 dan 0,20261 . Menggunakan $\alpha$ (taraf signifikansi) sebesar 0,05 , uji Glejser memberikan keputusan gagal tolak $H_{0}$ karena $p$-value $>\alpha$. Residual yang dihasilkan model memenuhi asumsi identik.

2. Asumsi Independen

Asumsi residual selanjutnya yang harus terpenuhi adalah independen. Metode yang dapat digunakan untuk menguji asumsi independen adalah melalui plot Autocorrelation Function (ACF) dengan hipotesis sebagai berikut.

$H_{0}: \operatorname{cov}\left(\varepsilon_{i}, \varepsilon_{j}\right)=0$

$H_{1}$ : paling sedikit ada satu $\operatorname{cov}\left(\varepsilon_{i}, \varepsilon_{j}\right) \neq 0, i \neq j$

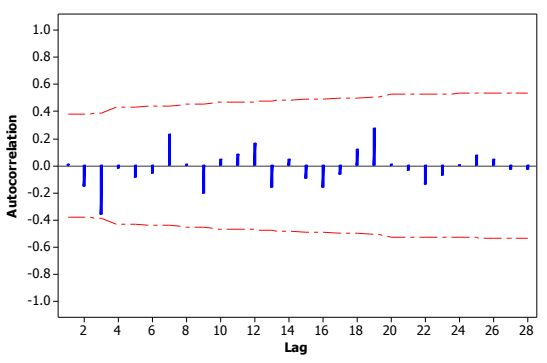

Gambar 3. ACF Residual

Berdasarkan Gambar 3, lag 1 hingga 29 tidak keluar dari batas signifikansi sehingga tidak terdapat kasus autokorelasi atau residual telah independen.

3. Asumsi Distribusi Normal

Pengujian asumsi distribusi normal menggunakan uji Kolmogorov-Smirnov dengan hipotesis sebagai berikut.

$H_{0}$ : Residual berdistribusi normal

$H_{1}$ : Residual tidak berdistribusi normal

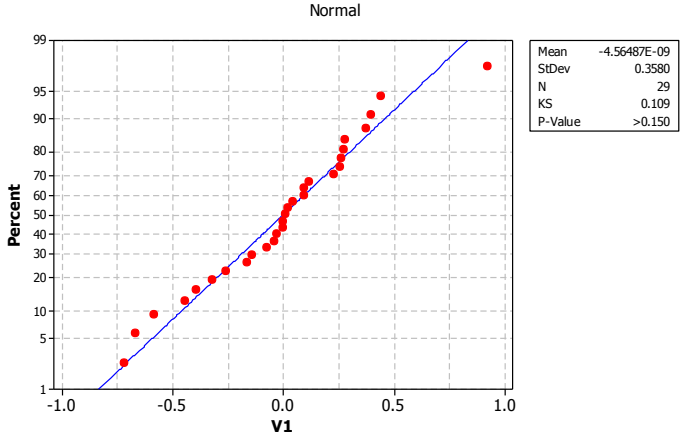

Gambar 4. Hasil Uji Kolmogorov-Smirnov

Keputusan uji Kolmogorov-Smirnov dapat diambil melalui $p$-value. Berdasarkan Gambar 4, nilai $\mathrm{p}>0,150$. Dengan menggunakan taraf signifikansi $(\alpha)$ sebesar 0,05 , uji Kolmogorov-Smirnov memberikan keputusan gagal tolak $H_{0}$ karena $p$-value $>\alpha$ sehingga residual model berdistribusi normal.

\section{G. Nilai Koefisien Determinasi $\left(R^{2}\right)$}

Model regresi terbaik memiliki koefisien determinasi sebesar $90,77 \%$. Angka tersebut berarti bahwa model dapat menjelaskan variasi variabel respon berupa rata-rata UKP Jawa Timur sebesar 90,77\%. Sedangkan sisa koefisien determinasi 9,23\% dijelaskan oleh variabel prediktor lain yang tidak masuk dalam model

\section{H. Interpretasi Model Regresi Nonparametrik Spline}

Setelah dilakukan pengujian asumsi pada residual model regresi semiparametrik spline dan didapatkan bahwa semua asumsi terpenuhi, selanjutnya dilakukan interpretasi model. Interpretasi ini dibuat berdasarkan model untuk setiap variabel untuk memudahkan dalam interpretasi.

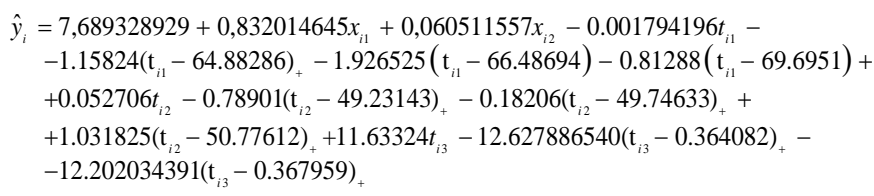


1. Hubungan antara rata-rata lama sekolah wanita terhadap rata-rata Umur Kawin Pertama (UKP) di Provinsi Jawa Timur dengan asumsi variabel prediktor lain tetap adalah sebagai berikut.

$$
\hat{y}_{x 1}=7,689328929+0,832014645 x_{i 1}
$$

Apabila rata-rata lama sekolah wanita di Jawa Timur naik satu satuan, maka rata-rata Umur Kawin Pertama wanita juga akan naik sebesar 0,8320. Hal ini berarti bahwa semakin lama seorang wanita di Jawa Timur menjalani sekolah, maka semakin tua wanita tersebut menikah, atau wanita tersebut akan cenderung menunda usia pernikahannya.

2. Hubungan antara persentase penduduk wanita yang tinggal di pedesaan terhadap rata-rata Umur Kawin Pertama (UKP) di Provinsi Jawa Timur namun dengan asumsi variabel prediktor lain tetap adalah sebagai berikut.

$$
\begin{aligned}
y_{t 1}= & -0.001794196 t_{i 1}-1.15824\left(\mathrm{t}_{i 1}-64.88286\right)_{+}-1.926525 \\
& \left(\mathrm{t}_{i 1}-66.48694\right)-0.81288\left(\mathrm{t}_{i 1}-69.6951\right) \\
= & \left\{\begin{array}{cc}
-0.001794196 t_{1} & t_{1}<64.88286 \\
75.134-1.16003 t_{1} & 64.88286 \leq t_{1}<66.48694 \\
141.62-3.086 t_{1} & 66.48694 \leq t_{1}<69.6951 \\
198.212-3.8985 t_{1} & t_{1} \geq 69.6951
\end{array}\right.
\end{aligned}
$$

Apabila persentase penduduk wanita yang tinggal di desa bernilai kurang dari $64,882 \%$ dan nilainya naik satu persen dengan asumsi prediktor lain tetap, maka rata-rata Umur Kawin Pertama (UKP) Jawa Timur akan turun sebesar 0,0017941. Terdapat 14 kabupaten yang termasuk ke dalam interval ini dan kebanyakan anggotanya merupakan kabupaten dengan kategori rata-rata umur kawin pertama marriage at mature. Apabila persentase penduduk wanita yang tinggal di desa bernilai antara $64,882 \%$ hingga $66,486 \%$ dan nilainya naik satu persen dengan asumsi prediktor lain tetap, maka rata-rata Umur Kawin Pertama (UKP) Jawa Timur akan turun sebesar 1,16003. Kabupaten yang termasuk ke dalam interval ini adalah Kabupaten Probolinggo. Kabupaten Probolinggo memiliki rata-rata umur kawin pertama terkategorikan dalam child marriage. Sementara apabila persentase penduduk wanita yang tinggal di desa bernilai antara $66,486 \%$ hingga $69,6951 \%$ dan nilainya naik satu persen dengan asumsi prediktor lain tetap, maka rata-rata Umur Kawin Pertama (UKP) Jawa Timur akan turun sebesar 3,086. Hanya terdapat satu kabupaten yang termasuk ke dalam wilayah interval ini yaitu Kabupaten Bondowoso yang memiliki rata-rata umur kawin pertama wanita terkategorikan ke dalam child marriage. Pada interval terakhir, apabila persentase penduduk wanita yang tinggal di desa bernilai lebih dari 69,6951\% dan nilainya naik satu persen dengan asumsi prediktor lain tetap, maka ratarata Umur Kawin Pertama (UKP) Jawa Timur akan turun sebesar 3,8985. Terdapat 13 wilayah atau kabupaten yang termasuk ke dalam interval ini dan didominasi oleh kabupaten yang memiliki kategori rata-rata umur kawin pertama early marriage.
Selanjutnya, interpretasi variabel komponen nonparametrik yaitu persentase penduduk wanita usia 15 tahun keatas yang bekerja dan gini ratio dilakukan dengan cara yang serupa seperti yang telah dijelaskan pada variabel persentase penduduk wanita yang tinggal di desa.

\section{KESIMPULAN DAN SARAN}

Terdapat 5 kabupaten yang tergategorikan menjadi child marriage, 13 kabupaten yang terkategorikan dalam early marriage, 11 kabupaten terkategorikan dalam marriage at maturity, dan tidak kabupaten yang terkategorikan dalam late marriage. Berdasarkan scatterplot antara rata-rata UKP Jawa Timur dengan setiap variabel yang diduga mempenaruhinya, terdapat 2 variabel komponen parametrik (rata-rata lama sekolah dan persentase penduduk miskin) dan 3 variabel komponen nonparametrik (persentase penduduk wanita yang tinggal di pedesaan, persentase penduduk wanita berusia 15 tahun keatas yang bekerja, dan gini ratio).

Model regresi semiparametrik spline terbaik untuk memodelkan rata-rata UKP Jawa Timur adalah dengan kombinasi titik knot 3,3,2. Dimana jumlah knot 3 untk variabel persentase penduduk wanita yang tinggal di desa, 3 untuk persentase penduduk wanita usia 15 tahun ke atas yang bekerja, dan 2 untuk variabel gini ratio. Variabel yang tidak berpengaruh signifikan terhadap rata-rata Umur Kawin Pertama Provinsi Jawa Timur adalah persentase penduduk miskin. Koefisien determinasi yang dihasilkan oleh model terbaik adalah sebesar $90,77 \%$.

Terdapat beberapa saran yang dapat diberikan oleh penulis yaitu bagi peneliti selanjutnya hendaknya menambahkan variabel lain yang diduga mempengaruhi ratarata Umur Kawin Pertama di Jawa Timur, dan menambah kemungkinan titik knot. Sedangan untuk pemerintah, rata-rata Umur Kawin Pertama di Jawa Timur masih rendah dibandingkan dengan daerah lain sehingga pemerintah dituntut untuk memaksimalkan program pencegahan pernikahan dini seperti PUP (Pendewasaan Usia Perkawinan) dan menambah sosialisasi mengenai program-program tersebut guna menambah kesadaran remaja untuk menunda usia perkawinannya. Apabila kebanyakan remaja sudah gagal menunda usia perkawinannya, maka akan lebih baik pemerintah memberikan sosialisasi hal-hal apa saja yang perlu disiapkan dalam sebuah pernikahan dan mewajibkan penggunaan alat kontrasepsi hingga usia istri mencapai 20 tahun untuk menghindari kelahiran anak di usia istri yang masih dibawah 20 tahun.

\section{DAFTAR PUSTAKA}

[1] Mantra, I. B. (2000). Demografi Umum. Yogyakarta : Pustaka Belajar.

[2] BAPPENAS. (2005). Laporan Perkembangan Tujuan Pembangunan Milenium Indonesia. Jakarta : BAPPENAS.

[3] PKPP. (2012). Faktor-faktor yang Mempengaruhi Usia Kawin Pertama pada Perempuan di Indonesia. Jakarta : Tim Implementasi PKPP 2012 Kementrian Riset dan Teknologi Republik Indonesia.

[4] BKKBN. (2013). Hubungan Antara Pengendalian Penduduk dengan Sosial Ekonomi di Propinsi Jawa Timur (Analisis Data Sensus Penduduk 2012, Susenas 2011-2012). Jawa Timur : BKKBN Jatim.

[5] Eubank, R. 1988. Spline Smoothing and Nonparametric Regression. Marcel Dekker Inc. New York. 
[6] Budiantara, I N. (2009). Spline Dalam Regresi Nonparametrik Dan Semiparametrik: Sebuah Pemodelan Statistika Masa Kini dan Masa Mendatang, Pidato Pengukuhan Untuk Jabatan Guru Besar Dalam Bidang Ilmu Matematika Statistika dan Probabilitas, Pada Jurusan Statistika, Fakultas MIPA, Institut Teknologi Sepuluh Nopember, ITS Press, Surabaya.

[7] Wahba.G. (1990). Spline Models For Observational Data. University Of Winsconsin at Madison.

[8] Eubank, R.L. (1999), Nonparametric Regression and Spline Smoothing Second Edition, Marcel Deker, New York.

[9] Gujarati, N. D. (2004). Basic Econometrics fourth edition. McGrawHill. 